\title{
"Such a section as never was put together before": Logan, Dawson, Lyell, and mid-Nineteenth-Century measurements of the Pennsylvanian Joggins section of Nova Scotia
}

\author{
Michael C. Rygel ${ }^{1 *}$ and Brian C. Shipley ${ }^{2}$ \\ 1. Department of Earth Sciences, Dalhousie University, Halifax, Nova Scotia B3H 4J1, Canada \\ 2. Department of History, Dalhousie University, Halifax, Nova Scotia B3H 4P9, Canada \\ *Present Address: Department of Geosciences, 214 Bessey Hall, University of Nebraska-Lincoln, \\ Lincoln, Nebraska, 68588-0340, USA <mrygel@unlnotes.unl.edu>
}

Date received:27 May 2004 g Date accepted: 28 January 2005

\begin{abstract}
William Edmond Logan assumed his duties as the first head of the Geological Survey of Canada in June 1843. Two previously overlooked field notebooks provide new insight into his first field project that summer: measurement of the "Joggins section," a classic Carboniferous locality in Nova Scotia. Inspired by reports of 40-foot-tall fossil trees, Logan spent five days measuring 14570 feet 11 inches of strata exposed along the shore of the Bay of Fundy. Widely regarded as a meticulous, bed-by-bed measured section, closer examination reveals that many thickness values were calculated using paced distances. Realizing that his measured section was too detailed for scientific journals of the day, Logan published his work in a relatively obscure government publication where it went largely unnoticed for nearly a decade. Unaware of Logan's measured section, John William Dawson and Charles Lyell visited Joggins in 1852 and measured the section for themselves. Dawson later stated that the two sections contain only minor differences, but careful comparison shows that they have radically different descriptions and measurements for even the most distinctive beds. Dawson disguised these discrepancies in post-1855 editions of his book Acadian Geology by rewriting much of the measured section and abandoning many of his own observations. Although over 200 subsequent Joggins studies build upon these measured sections, the present study represents the first detailed examination of the two historical sections and reveals previously unknown discrepancies between two of the most important early geologic studies undertaken in Nova Scotia.
\end{abstract}

\section{RÉSUMÉ}

William Edmond Logan est devenu le premier responsable de la Commission géologique du Canada en juin 1843. Deux carnets de travaux sur le terrain, précédemment négligés, fournissent un nouvel éclairage sur son premier projet sur le terrain cet été-là : le mesurage du «stratotype de Joggins », un secteur carbonifère classique en Nouvelle-Écosse. Inspiré par des comptes rendus de la présence d'arbres fossiles de 40 pieds de hauteur, Logan a consacré cinq jours à mesurer 14570 pieds 11 pouces de strates affleurant le long du rivage de la baie de Fundy. Un examen plus attentif de l'endroit, largement considéré comme un stratotype méticuleusement mesuré couche par couche, révèle que de nombreuses données d'épaisseur ont été calculées au nombre de pas. Se rendant compte que le stratotype qu'il avait mesuré était trop détaillé pour les revues scientifiques de l'époque, Logan avait publié ses travaux dans une publication gouvernementale relativement obscure où ils sont demeurés pratiquement inaperçus pendant près d'une décennie. John William Dawson et Charles Lyell, qui n'étaient pas au courant du stratotype mesuré par Logan, se sont rendus à Joggins en 1852 et ont mesuré le stratotype eux-mêmes. Dawson a ultérieurement laissé entendre que les deux stratotypes présentaient seulement des différences minimes, mais une comparaison attentive révèle que leurs descriptions et leurs mesures sont radicalement différentes, même dans le cas des couches les plus caractéristiques. Dawson a déguisé ces divergences dans des éditions ultérieures à 1855 de son livre Acadian Geology en remaniant une vaste part du stratotype mesuré et en abandonnant nombre de ses propres observations. Même si plus de 200 études subséquentes de Joggins se sont appuyées sur les stratotypes mesurés, la présente étude représente le premier examen détaillé des stratotypes et elle révèle des divergences auparavant inconnues entre deux des premières études géologiques les plus importantes réalisées en Nouvelle-Écosse.

[Traduit par la rédaction] 


\section{INTRODUCTION}

Sir William Edmond Logan (1798-1875; Fig. 1), widely regarded as the "Father of Canadian Geology," began his prestigious Canadian career in earnest in June 1843 along the shores of the Bay of Fundy at "the Joggins." Appointed in 1842 as the first head of the Geological Survey of Canada, as the new institution eventually became known, Logan's mandate was to assess the mineral resources of the Province of Canada (the southern parts of modern Quebec and Ontario). He prepared for this undertaking by visiting coal-bearing Carboniferous outcrops in Nova Scotia and New Brunswick, then separate British colonies, before continuing north to search for coal in the older, poorly known rocks of the Gaspé Peninsula.

While in Nova Scotia, Logan measured the 14570 foot 11 inch "Joggins section", a gently dipping coastal exposure along the southern shore of Chignecto Bay, near the present village of Joggins, Nova Scotia. Although this measured section is the framework upon which all subsequent studies have been built,

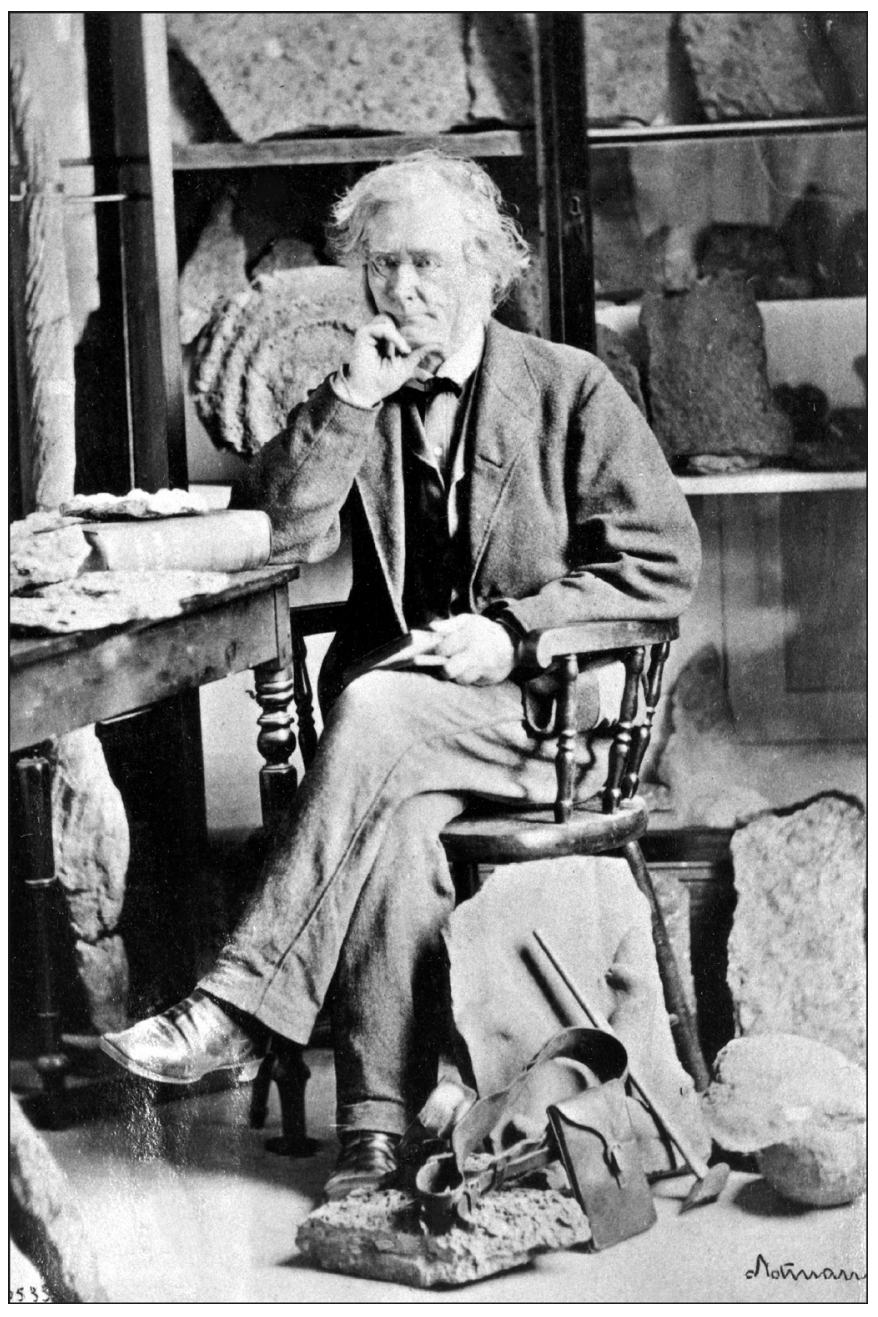

Fig. 1 Sir William Edmond Logan, 1865. Photograph by William Notman, Montreal, Quebec; reproduced with permission of the McCord Museum of Canadian History, Montreal (accession number I-16533.1). the most specific information about Logan's time at Joggins is Harrington's (1883) report that "At the South Joggins he spent several weeks, and it was at this time that he executed his great section of the coal-measures which, as has been truly said, is 'a remarkable monument of his industry and power of observation." In this paper, we describe the events that brought Logan to Joggins and use his original field notebooks to provide the first detailed information about the construction of his famous measured section.

We then compare Logan's work to a little-known measured section of the "classic" Joggins section (i.e. Logan's Division 4) measured by John William Dawson and Charles Lyell nine years after completion of Logan's section. Despite Dawson's claim that the measured sections contain only "minor differences," careful scrutiny reveals that they provide very different descriptions and thicknesses even for distinctive beds. Our examination of Dawson's work clearly demonstrates that he disguised these discrepancies in post-1855 editions of Acadian Geology by abandoning many of his own observations. Lastly, we review the historical and scientific significance of the measured sections.

\section{LOGAN'S INTEREST IN COAL}

William Edmond Logan was born in Montreal on Friday, 20 April 1798. After attending high school in Scotland, Logan briefly attended Edinburgh University before joining his uncle's counting house in London in 1817 (Harrington 1883; Alcock 1948; Smith 2000).

Logan's life changed direction in 1831 when he left London to work in his uncle's copper smelting business near Swansea, Wales. Logan was initially employed as an accountant and bookkeeper, but soon became interested in technical and scientific aspects of the business. In an 1833 letter to his brother he remarked that "Here I am, out of the world altogether, and attending to nothing else but the making of copper and the digging of coal from morning till night" (quoted in Harrington 1883). Coal was a heavily used material in the smelting operation, and Logan soon became interested in its origin and distribution in the surrounding Glamorganshire coalfield (Torrens 1999; we concur with Torrens in doubting the assertion by Christie, 1995, that Logan's avowed interest in economic matters was purely deception). With his personally purchased compass and theodolite, Logan began to make detailed geologic maps of the area using the one-inch sheets of the Ordnance Survey as a base (Bailey 1952), maps that Sir Henry De la Beche later adopted as official documents of the Geological Survey of Great Britain (Smith 2000).

Logan's geologic prowess began to attract the attention of prominent figures of the day and he was elected as a Fellow of the Geological Society in 1837 (Torrens 1999). Shortly thereafter, he stated his geological aspirations in a letter to his brother: "I take a great interest in the science, and some day or other I may appear in print... If I ever return to Canada again I shall geologize there" (quoted in Harrington 1883). Following the death of his uncle, and without any definite plan for future 
employment, Logan resigned his position at the copper works in 1838.

The years 1838 through 1841 were a period of intellectual and professional freedom during which Logan brought his investigation of the origin of coal to fruition. Although the botanical origin of coal became generally accepted during the early 1800 s, there was still considerable debate about whether it was transported and deposited subaqueously (an idea termed the "drift theory") or accumulated in situ (Stevenson 1911). While Logan was mapping in Wales, coal miners brought the rooted underclays beneath coal seams to his attention(Torrens 1999). Realizing that the stigmarian roots were part of the plants that made up the coal seams, Logan communicated his observations to the Geological Society of London in February 1840 and later published them as an abstract in the Proceedings (Logan 1840) and in full in the Transactions (Logan 1842a).

The discovery that South Wales coal seams always occurred atop rooted seat earths (underclays) thus became Logan's claim to fame. The desire to extend the generality of this observation to other regions was a key motive of his actions over the next several years.

\section{LOGAN RETURNS TO NORTH AMERICA}

Although free from daily business commitments, Logan still had to deal with many of his deceased uncle's affairs on both sides of the Atlantic(Torrens 1999; Logan to De la Beche, 3 Dec 1841, De la Beche Papers). Obliged to sail for Canada in August of 1840, he decided to take this opportunity to examine the geology of eastern North America. Upon arriving in Nova Scotia, Logan took a stagecoach between Halifax and Pictou, recording as many impressions of the passing geology as he could (Logan 1841a). He continued on immediately to Quebec, and spent much of the next year examining the geology of the Montreal area (where his older brother James still lived), analyzing modern phenomena such as the accumulation of ice on the St. Lawrence River and a landslide south of the city (Logan 1842b, 1846). He planned to return to Britain in August 1841, but a delayed meeting in New York City allowed him enough time to visit the coalfields of eastern North America before his departure. While making arrangements to tour the eastern coalfields, Logan spotted Charles Lyell in the street and briefly met with him on Sunday, 15 August to discuss Logan's work on underclays, the Welsh coalfields, and Lyell's planned visit to Canada the following year (Harrington 1883).

After a short visit to eastern Pennsylvania, Logan continued on to Saint John, New Brunswick, with hopes of meeting Abraham Gesner, a Maritime geologist and physician. Finding that Gesner was in the field at Miramichi, Logan crossed the Bay of Fundy to investigate the geology near Windsor, Nova Scotia, where he made his famous discovery of tetrapod trackways (Dawson 1855). The tour of Nova Scotia concluded with a week long excursion to the Pictou coalfield, during which Logan was "delighted" to have the company of William Dawson - a young and knowledgeable geologist from the area (Logan 1841a; Harrington 1883). For Logan, the opportunity to confirm that the Stigmaria-bearing underclays he had first observed in South Wales also occurred in North America was a crucial step in establishing the superiority of his in situ theory of coal formation over the older, formerly generally accepted theory of drift (Logan 1841b).

\section{BIRTH OF THE CANADIAN SURVEY}

Much like oil today, coal was the single most important energy source during the nineteenth and early twentieth centuries. The industrial supremacy of Britain, and later the United States, was fueled by it (Freese 2003). Coal provided energy for transportation, heat for homes, freed factories from the need for hydraulic power, and was crucial for the production of iron (Zaslow 1975; Freese 2003). Although the Province of Canada's economy in the first half of the nineteenth century was based largely on supplying raw materials, the province was keen to develop its mineral resources and secure its place in the transforming global economy. The British colony of Nova Scotia had economic Carboniferous coal deposits (Calder 1985), but their geologic relationship to the rocks of Ontario and Quebec was unknown. Without the benefit of modern stratigraphic concepts, attempts to find and predict coal occurrences (even within known coalfields) were haphazard at best (Zaslow 1975). Few people had the necessary training to determine the extent of the coalfields, and securing and funding one of these individuals would require a national effort.

The need for a geological survey of Upper and Lower Canada became apparent in the early 1830s, but political unrest stalled serious planning for over a decade (Zeller 1987). In September 1841 , the government agreed to have a survey carried out, provided that it cost less than $£ 1500$. Shortly thereafter, Governor General Sir Charles Bagot began what was to be a very short search for the right candidate.

Logan first heard about the possibility of a Canadian survey in 1841, while preparing to travel to Pennsylvania and Nova Scotia (Zaslow 1975). During his tour of the American coalfields, Logan wrote that "I have almost made up my mind, if I can make the necessary arrangements in business matters, to offer myself as a candidate to undertake the survey of Canada, and if I once begin, it will not be my fault if it does not go ahead" (Harrington 1883). Shortly after the funds were allocated, lobbying by Logan's supporters on both sides of the Atlantic quickly convinced Sir Charles Bagot that Logan was the right choice for the job. In February 1842, Bagot asked the Colonial Secretary in London, Lord Stanley, to offer Logan the position if his letters of reference were favorable (Zeller 1987). Four of the most influential British geologists wrote on Logan's behalf: British Geological Survey director Henry De la Beche, Oxford University's William Buckland, Geological Society president Roderick I. Murchison, and Adam Sedgwick of Cambridge University (Harrington 1883).

Lord Stanley's undersecretary, G.W. Hope, offered William Logan the position of "Provincial Geologist" on 9 April 1842, 
an offer he accepted by letter on 14 April (Zaslow 1975). Logan reported to Kingston, then the Canadian capital, in late August to negotiate the details of his employment, but a political crisis prevented him from meeting with the provincial government until several weeks later. In the interim, Logan went on several field excursions, met with individuals knowledgeable about the regional geology, and assembled a collection of the existing geological literature and maps (Harrington 1883). With the government's permission, Logan returned to Britain for the winter of 1842-43 to fulfill several professional engagements and to review the existing geologic documents. Having completed a 5000-word "Preliminary Report" in December 1842, Logan spent the spring of 1843 in South Wales training his assistant, Alexander Murray (1810-1884), a retired naval officer and future director of the Geological Survey of Newfoundland, for their upcoming fieldwork in Canada. Murray departed for the flat-lying early Paleozoic formations of Canada West (Ontario) in April 1843 (Murray to De la Beche, 19 April 1843, De la Beche Papers), followed shortly thereafter by Logan who was destined for the deformed Paleozoic strata in the easternmost part of Canada, on the Gaspé Peninsula (Zaslow 1975). If the Carboniferous deposits of the Atlantic colonies extended into Canada at any point, it would have to be here. Thus, the most logical starting point for the search for coal in the Province of Canada was the known coalfields in the British colonies of Nova Scotia and New Brunswick.

\section{THE JOGGINS SECTION}

\section{Introduction}

Logan's personal journals and Geological Survey of Canada documents provide researchers with a wealth of information about his activities after his early-July arrival in Gaspé. Conversely, very little documentation exists for his monthlong trip through Nova Scotia and New Brunswick en route to his final destination (Fig. 2A). The best surviving records of this journey are Logan's two previously unexamined field notebooks (Logan 1843a, b), a series of letters written to De la Beche around this time (see Sharpe \& McCartney 1998), and Logan's (1845) report to the Legislative Assembly of the Province of Canada. We have used these resources to provide the first detailed account of Logan's visit to the Joggins section - an important but poorly understood contribution to the geology of Nova Scotia.

In late 2005 many of the original documents described in this paper were made available on the "Written in Stone" website (Library and Archives Canada 2005). This valuable resource also provides a link to the "Early Canadiana Online" project (Canadian Institute for Historical Microreproductions 2005) which contains images of Logan's (1845) "Report of Progress for 1843." The printable facsimiles of the original Joggins measured section contained therein make an excellent companion to the present paper (images W29 to W45, http://www.canadiana.org/ ECO/PageView/9_00955_4_1/0554).
Logan's primary goal for the summer of 1843 was to survey the strata of the Gaspé Peninsula to determine if they lay above or below the Carboniferous (Shipley 2002). Rather than sailing immediately to the Gaspé, Logan decided to take the overland route through Nova Scotia and New Brunswick to familiarize himself with known coal-bearing strata to the south. Logan had not visited Joggins on his two previous trips through Nova Scotia because it was off the main Halifax-Truro-Pictou transportation axis and because he missed meeting with Abraham Gesner, who was well aware of its existence (Gesner 1836; Logan 1841a). Gesner accompanied Charles Lyell on his visit to the site in 1842, and Lyell's published account of his observations of fossil trees in situ there was helping to bring wider attention to this important area (Lyell 1843a, 1845; Wilson 1998; for other early accounts see Jackson and Alger 1828; Brown and Smith 1829).

Logan had communicated with Lyell about Nova Scotian geology immediately before departing for Canada in 1843. Lyell suggested that they look over a map of the region together and told Logan that the Geological Society was particularly interested in the observations they had both made on Stigmaria underclays (Lyell to Logan, 13 April 1843 \& 27 April 1843, Logan Papers). Thus, Logan's trip to Joggins would provide the foundations for his official search for Canadian coal, allow him to pursue his research on the formation of coal, and put his personal stamp on an increasingly important locality.

Upon arriving in Halifax at 10 a.m. on Tuesday 30 May 1843 aboard the SS Acadia, Logan spent much of that day and the next purchasing field supplies (knapsack, fishing basket, bird shot, etc.) and arranging to have his "traveling laboratory" sent on to Gaspé by boat. Logan's familiarity with Gesner and Lyell's work at Joggins is evident from his 31 May 1843 letter to De la Beche, in which he stated his first goal: "I shall pay a visit to the Joggins, where Lyell saw the vertical trees, \& I shall endeavour to determine the thickness of the whole deposit there. Dr. Gesner says it is 5 miles thick \& Lyell says that it dips one way for a distance of 35 miles" (De la Beche Papers). Logan left Halifax on 1 June, making his way toward the Bay of Fundy by foot and by coach. He arrived in Minudie on 4 June with the intention of starting work at Joggins the following day; but heavy rain caused a one-day delay, during which he measured sections in and around Minudie.

\section{Logan's Measurements}

Logan measured 14570 feet, 11 inches of strata exposed along the Chignecto coast between 6-10 June 1843 (Fig. 2B). From his starting point at Mill Cove, Logan worked up section, measuring about 3700 feet of strata in his first day and about 4700 feet in his second. The accelerated pace of the second day was checked, however, as he entered coal-bearing strata; 3900 feet of section between what would become Coal 34 (Division 4) and Ragged Reef Point were measured on Thursday 8 June. With dips of about $15^{\circ}$ on the fourth day, the increasing horizontal distance per unit thickness became apparent because it took all of Friday 9 June to measure the 1360 feet of section 


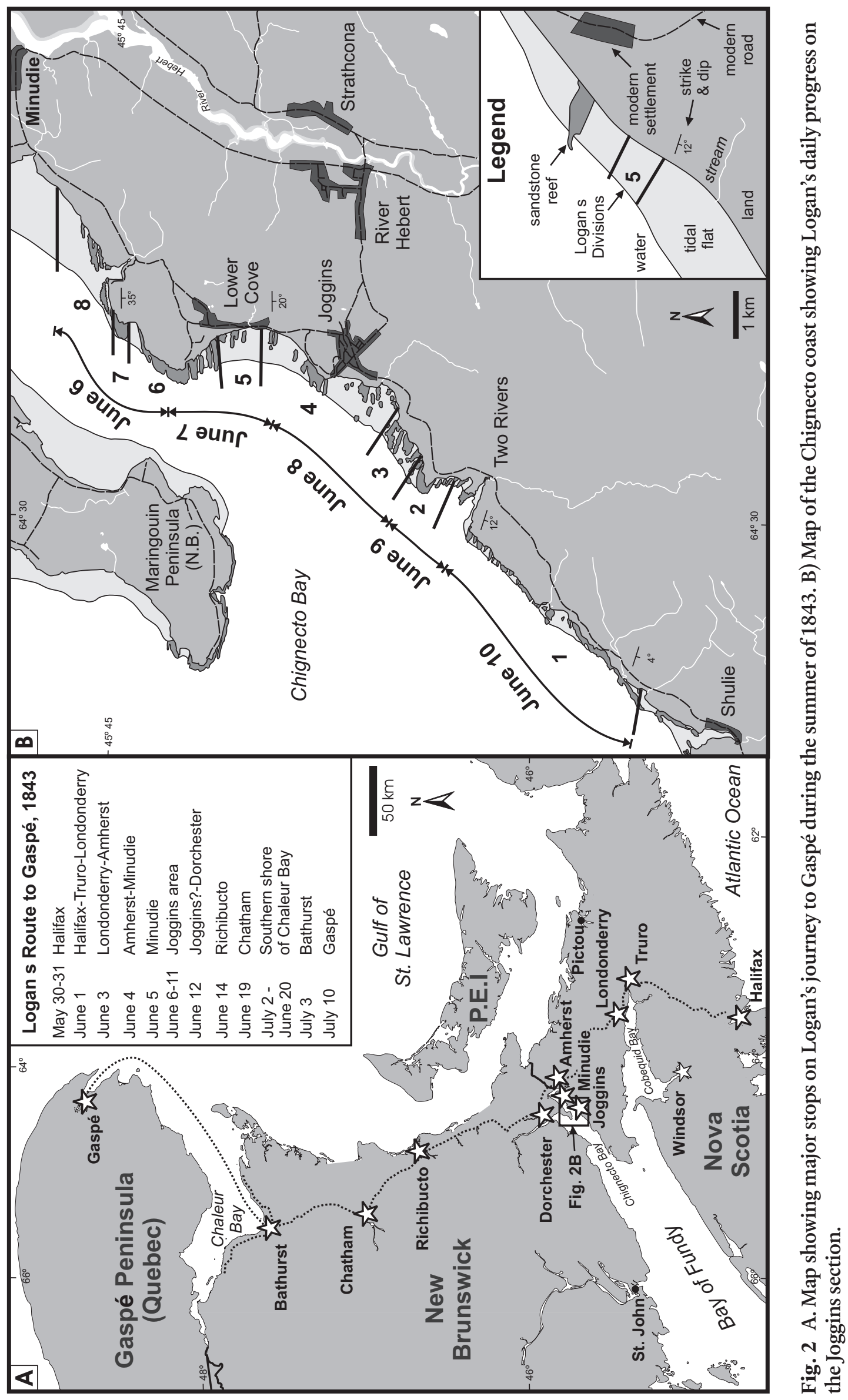


from Ragged Reef Point to West Ragged Reef Point. After measuring an additional 868 feet on Saturday 10 June, Logan concluded his traverse, reasoning that because the "dip is reduced by a very small angle, it is likely that a farther investigation would require a longer walk than I can afford" (Logan 1843b, p. 53). Logan made no mention of his whereabouts on Sunday 11 June, but his notes indicate that he took the day off before moving on to Dorchester on Monday morning.

From a logistical perspective, the Joggins work differed significantly from his later work in Gaspé. A sparse population of settlers lived in the Joggins area by the early 1840s and Logan was able to find lodging with them for the duration of his stay, rather than having to make his own camp outdoors. Logistics were also simplified because Logan had only to provide for himself and a local assistant who he employed for three and three-quarters days. Realizing that his work in Nova Scotia was mainly reconnaissance, Logan did without the more complex surveying equipment employed in later projects (von Bitter 1998) and used only his own pace, a compass, and basic field gear (e.g. measuring stick and hammer) to measure the section.

The field notebooks show that Logan continually adapted his methodology to suit the changing nature of the section. The first few pages of notes for 6 June record four types of information for each bed: number of paces, lithology, true thickness, and dip (Fig. 3A). Apparently realizing the enormity of his task, dip measurements become more infrequent (every few hundred feet of section) by the middle of the day. When evaluating Logan's work at Joggins it is important to remember that, although he considered the section bed-by-bed, he routinely grouped together what by modern standards would be several beds (see Davies et al. 2005). Taken with other evidence (see below), the pace-lithology-thickness-dip style of note-taking records the process of pacing the horizontal extent of the beds, a measurement from which the true thickness was apparently calculated. With the transition to coal-bearing strata on 7-8 June, Logan began recording only the thickness and lithologic description for each seam and closely associated strata (Fig. 3B). The absence of pace counts for each bed represents a transition to direct measurement for these organic-rich intervals. For clastic intervals more than a few feet thick, Logan returned to pacing in order to determine bed thickness. Realizing that direct measurement was the most efficient way to proceed through gently dipping strata, Logan's notes from 10 June indicate that he adopted this methodology for measuring the redbed-dominated interval north of Two Rivers (Fig. 3C). Despite his rapid pace, Logan took the time to make several detailed sketches of particularly interesting features of the section (Fig. 3D).

Logan's habit of first writing his notes in pencil, only later inking them over, makes them difficult to read in places, but provides convincing evidence that he commonly calculated thickness values after leaving the section. Although clastic intervals are accompanied by notes on the number of paces, lithology, and thickness, only the first two values are always written in pencil (Fig. 3A-C). Conversely, coal-bearing units always have lithology and thickness values written in pencil (Fig.
3B). Several beds observed on Friday 9 June are accompanied only by pace values (written in ink and pencil; Fig. 3C), demonstrating that paces were often the only measure of thickness collected in the field.

Indeed, it appears that Logan may not have inked over and finalized his Joggins notes until long after he left the section. In order to calculate the thickness of each bed, Logan had to multiply the number of paces by the length of his pace (our calculations indicate 2.9 feet) and the sine of the dip. No such calculations appear anywhere in his field notebooks, and it is unlikely that he would have had sufficient time to manually perform hundreds of trigonometric calculations after having spent lengthy days on the section. The absence of thickness values for observations on 9 June (Fig. 3C) indicates that the final calculation of bed thicknesses were made after he inked over the notes. Post-Joggins revision to the measured section is also apparent because numerous thickness values reported in the published version do not match the values in his notes, a discrepancy that either reflects a typographical error or, more likely, ongoing mathematical adjustments to the section. Logan hinted at post-Joggins calculation of thickness in a letter to De la Beche on 20 April 1844, mentioning that "since my return from field-work I have reduced all the measurements, and made out a vertical column" (De la Beche Papers).

Logan wrote to De la Beche several times about Joggins. Clearly delighted with his results there, he had first written to his mentor at the British survey while en route back from Nova Scotia to Canada. Writing from Bathurst, New Brunswick, just before he crossed Chaleur Bay into Gaspé, Logan said:

I think I mentioned to you that I intended to visit the Joggins. I did so \& spent a week putting together such a section as never was put together before. I measured and made a written description of every bed (\& I don't suppose that in the whole distance there were 1500 feet not visible) occurring in 10 miles to a line directly across the strata, commencing with a dip of $45^{\circ}$ in the

Fig. 3 (Facing page) Pages from William Logan's field notebooks from Joggins, Lighter writing represents the original text (pencil), darker writing is the finalized text (ink). A. Logan's notes for the base of Division 8 showing the pace-lithology-thickness-dip style of note-taking used when pacing clastic intervals (Logan 1843a, p. 37). B. Notes for part of Division 4 (Logan 1843a, p. 126). Note that Logan used the lithology-thickness style of note-taking for the coal-bearing interval, indicating that he measured these beds directly (no paces recorded). This contrasts with the over- and underlying clastic intervals where values are provided for both the thickness and the number of paces. C. Logan's notes for part of Division 2 with only pace and lithology recorded, a strong indicator that many thicknesses were calculated after Logan left the section (Logan 1843b, p. 42). D. Field sketch of an upright tree in Division 4 (Logan 1843a, p. 116). 

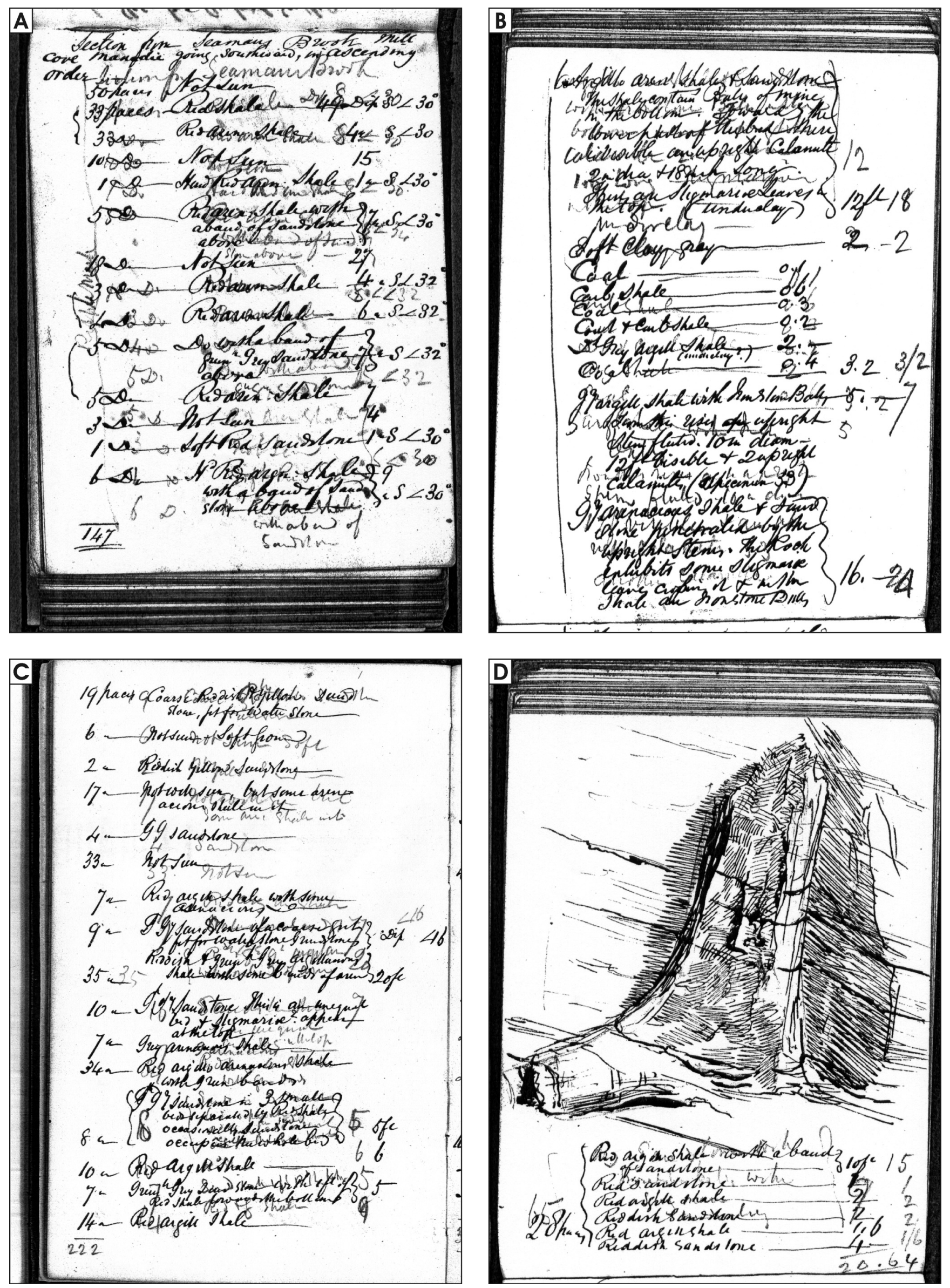
lower part and ending (the change being gradual) with a dip of $4^{\circ}$ in the upper. [Logan to De la Beche, 2 July 1843, Phillips Papers]

In this letter, Logan also mentioned that he was sending a box of Joggins fossils to De la Beche for analysis, and hoped that they would arrive safely. These fossils were collected to determine the depositional environments and age of these strata, but this aspect of Logan's plan was not destined for positive results.

\section{Publication of Logan's Measured Section}

With his observations and calculations neatly rewritten, Logan's Joggins measured section was nearly complete by April 1844. Still awaiting feedback on the specimens sent to De la Beche (also mentioned in the field notebooks), Logan wrote on 20 April, "My Dear De la Beche, How is it that you have never written to me? Did you get my letter from Bathurst, \& did you get the Box of Specimens sent you from Nova Scotia?" Realizing the global significance of this section, he went on to explain:

I am getting a written copy of it made for you, but it takes much time. It may be very useful to you in speaking of coal in general in your report. I mean to get the document published somehow or other, \& I should be glad if you would allude to it publicly if it illustrates anything you may have to say on South Wales. The detail will surprise you. You can make a public document of it if you like, by communicating it to the Geological Society. I am aware they would not print it; there is not poetry enough about it for their pages. But were it among their documents, you could then allude to it with more propriety, if you think it worth while. I cannot help thinking it will be considered very instructive in showing the composition of a coal-field. [De la Beche Papers]

By November 1844, the lines of communication had not improved. Just over two weeks before his "Report of Progress" for the previous year was turned in, a frustrated Logan outlined his situation in another letter to De la Beche:

In this one letter I have received from you, you speak of another previous dispatch which you have sent. This has never come to hand. You say nothing of any communication from me. So I am anxious to know whether you ever got my Joggins Section, \& what you think of it. It is a work of no small labour \& I hope something will come of it. Will it be useful to you in what you will have to say of the Welsh Coalfield. Perhaps you have not got it at all and I should like to know if such should be the case. A year \& a half ago I sent you or rather put on the way of being forwarded to you a box of specimens from the Joggins; did this ever reach you? I have heard nothing of it since, not withstanding I have asked you three times to say, fish jaws and fish scales associated with Stigmariae were among the specimens (Logan to De la Beche, 11 November 1844, De la Beche Papers).

Unfortunately, Logan's hopes for close collaboration between the Canadian and British surveys proved to be impractical (despite the claim made by Christie 1995). John Phillips, paleontologist to the Geological Survey of Great Britain, already had more work than he could handle, and the logistics of managing the rapidly growing Canadian collection were impractical in the extreme. Although De la Beche appears to have sent Logan's Joggins fossils on to Phillips, nothing was ever published as a result (Phillips to De la Beche, 10 August 1843, De la Beche Papers). In later years, Logan would make use of U.S. paleontologists such as James Hall of the New York survey, and eventually added his own paleontologist, Elkanah Billings, to the Geological Survey of Canada in 1856 (Zeller 1987).

To publish his Joggins section, Logan turned instead to his mandatory annual report. Although Logan loathed having to submit yearly progress reports to the government (Shipley 2001), the first installment provided him with a convenient vehicle for publishing a full copy of the Joggins measured section. The "Report of Progress for 1843," with its accompanying Joggins measured section, was presented to the government on 27 January 1845 . These works, together with a letter from the Governor General, Logan's 1842 "Preliminary Report” and a report from Alexander Murray, make up the forty-five pages of Appendix W in the fourth volume of the Journals of the Legislative Assembly of the Province of Canada 1844-5.

The final version of the Joggins measured section covers seventeen pages and includes six figures (Logan 1845, pages W-29 to W-45). The 14570 feet, 11 inches of strata in the section consist of 1570 beds grouped into eight Divisions (following the original work, the " $\mathrm{d}$ " in "Divisions" is capitalized and each is designated with a number). Coal-bearing intervals were of particular interest, and Logan designated numbered "Coals" and "Coal Groups" in each of the Divisions. Although Logan measured the section from bottom to top, he presented the published measured section in descending order so that the youngest (uppermost) strata fall within Division 1 and the oldest (lowermost) fall within Division 8. Logan was unhappy with the report's "awkward appearance" and made a point of telling De la Beche:

If you had sent me the names of the shells, fish scales
$\&$ jaw \& plants which I forwarded to you all num-
bered, my section would have had a most learned air.
I have sent a copy of the report to the President of the
Geological Society. I hope he will be able to speak well
of my name. I have been diligent; that I will say for
myself. [Logan to De la Beche, 27 December 1845,
De la Beche Papers]

Ironically, because Logan sent his fossils to Britain, he was not even able to refer to them himself as he prepared the re- 
port (Logan to Lyell, 10 January 1853, Lyell Papers). Logan was dissatisfied with the inclusion of his reports in a volume of government proceedings, complaining "who the devil ever reads a report" (Logan to De la Beche, 10 December 1846, De la Beche Papers). His personally-distributed copies were not enough to counter the obscurity (outside of Canada), small print runs, and limited distribution of the Legislative Assembly's Journals, and so for many years after its publication Logan's geological work reached a much more limited audience than it should have (Shipley 2001).

Poole (1908) republished the text portion of the section (in Proceedings and Transactions of the Nova Scotian Institute of Science - a journal that is itself rather difficult to locate), but he did not have the original woodcuts and was unable to duplicate the figures that accompanied it. Although Poole's republication made the content of the section more accessible, his citation made the original nearly impossible to locate. Poole (1908) stated that the measured section was "published as an appendix in the first Report of Progress of the Geological Survey, for 1843 , beginning at page 92 , and extending to page 156 , with figures on pages 157 to 159 ." By citing a rare offprint version of this report, rather than referring to its original place of publication in the Legislative Journal Appendices, Poole inadvertently obscured important information about the Canadian survey's early work; most of the geological literature in the last hundred years (even the Georef database) reference the section using Poole's misleading citation. With such convoluted information about the original work, most library photocopy requests are unsuccessful, resulting only in delivery of Poole (1908). By reintroducing the geological community to Logan's (1845) original section, we hope to draw attention to this remarkable work and facilitate proper citation in future papers.

\section{LYELL \& DAWSON}

\section{Visits to Joggins}

Logan was not the only Canadian geologist to publish a Joggins section. Another section was produced by John William Dawson (1820-1899), who first visited Joggins in the 1830s. Dawson later recalled of this trip that "I returned in the evening to the quarryman's shanty, thoroughly fatigued, but loaded with fossils, delighted with the knowledge I had acquired, and with my enthusiasm for geology raised to a higher point than ever before" (Dawson 1901). In the company of Abraham Gesner, the eminent British geologist Charles Lyell (Dawson's mentor), had made his first examination of the section in July 1842 (Dott 1996; Wilson 1998). Having personally witnessed a 25 -foot-tall standing lycopsid trunk and discovering that Gesner once measured one 40 feet tall (Lyell 1842; Wilson 1998), Lyell wrote to his sister that the Joggins fossil forests were "the most wonderful phenomenon perhaps that I have ever seen" (30 July 1842, in K.M. Lyell 1881, pp. 64-66). Lyell's observations at the Joggins section were communicated to the Geological Society of London (Lyell 1843a, b) and featured prominently in his Travels in North America (Lyell 1845). With both of their appetites thus whetted, mentor Lyell and protégé Dawson returned to the section together in 1852 to spend a few days exchanging ideas and investigating the preservation of standing trees (Sheets-Pyenson 1996).

During this visit, the two lacked the advantage of Logan's measured section. During their five-day stay in September 1852 (Wilson 1998), they examined much of the coal-bearing interval near Joggins village and measured their own 2819 foot, 2 inch section. While breaking apart lycopsid casts in search of plant material, they stumbled across a diverse assemblage of animal remains, including reptile bones and land snail shells (Lyell and Dawson 1853). Delighted with their discoveries, Lyell wrote to his father-in-law, Leonard Horner, on 12 September that "I never enjoyed the reading of a marvelous chapter of the big volume more" (K.M. Lyell 1881, pp. 178-184).

Following his visit to the Joggins section, Lyell became aware of Logan's measured section, but neither he nor Dawson could easily find any record of it in print. On 16 December 1852, Lyell requested a copy, to which Logan replied on 10 January 1853 that he had sent copies to the geological establishments in Britain and even to Lyell himself(Logan Papers; Lyell Papers). Logan's claim is supported by the fact that Leonard Horner (as President of the Geological Society of London) described Logan's section in great detail in his anniversary address to the Society (Horner 1846). This awkward exchange, described more fully by Shipley (2001), emphasizes both the inaccessibility of the measured section and the lack of communication between Logan on the one side, and Dawson and Lyell on the other. Sheets-Pyenson (1996, p. 24) speculated that there may have been personal friction between Logan and Dawson, noting that Dawson was not recruited for the Canadian survey and that Lyell often acted as their liaison even when they both lived in Montreal. Alternately, their less than perfect communication during the 1840s may simply have reflected their busy careers and the sheer press of work that affected them. Whatever the case, after Dawson's appointment to McGill University in 1855, Harrington (1883) describes their relationship as close and co-operative - an observation supported by Logan's large donations to McGill University in his will.

With the benefit of additional observations during the following summer of 1853 , Dawson finished the section by himself because Lyell had been called away to serve as commissioner to the New York Industrial Exhibition (Wilson 1998). He then gave the section to Lyell to communicate to the Geological Society of London on 2 November 1853 (Dawson 1854). Dawson published his measured section as a list of lithologies and thicknesses that are subdivided into twenty nine "Groups" (later referred to as "Subdivisions," both of which are designated with Roman numerals). Dawson's measured section was accompanied by a five-page commentary on the sedimentology, a fourteen-page description of the Groups and, having eventually secured a copy, a précis of Logan's work. In comparing the two measured sections, Dawson mentioned that the "number of coals and bituminous limestones seen by us corresponds with that of Mr. Logan," and that any discrepancies arose from "dif- 
ferent estimates of the limits of beds, from the obscuration of portions of the section, and from the circumstance that many beds called by us sandstones, or argillaceous sandstones, appear in Mr. Logan's section as arenaceous shales" (Dawson 1854, p. 41). He also mentioned that his measured section corresponded to the lower part of Logan's Division 3 (Groups XXVIII and XXIX) and all of Division 4 (Groups XXVII through I). Despite the harmony implied by these comments, careful scrutiny reveals differences so profound that Dawson largely abandoned his own observations when he reproduced this section in post1855 editions of Acadian Geology (Fig. 4).

\section{Comparison of the Measured Sections}

Lateral changes in bed thickness and ongoing erosion of the cliffs (up to $50 \mathrm{~m}$ in the last 150 years) makes detailed comparison of Logan and Dawson's sections with the modern coastal section problematic. Despite these changes, comparison of cumulative thicknesses and beds with relatively constant thicknesses (e.g. coals, limestones, and some sandstones) makes certain comparisons possible. Logan reported a thickness of 2533 feet, 7 inches for the interval between the top of the limestone in Coal Group 1 and the base of Coal 45, whereas Dawson's measured section gave a thickness of 2616 feet, 8 inches for the same interval, which is 83 feet, 1 inches (3.3\%) thicker than Logan's estimate. This comparison is based on the questionable assumption that Dawson correctly matched his measured section to Logan's. The calcareo-bituminous shale at the top of Group XXVII almost certainly corresponds to Logan's bituminous limestone (Fig. 4A, B), but Dawson's judgment that the lowest coal in Group I matches Logan's Coal 45 is problematic because the bituminous limestone that Dawson observed near the base of Group I is a lithology that last occurs in Logan's Coal Group 44 (Fig. 5D, E). If Dawson did mismatch the base of the sections, the difference between the measured sections increases to 191 feet, 9 inches, an increase of 7.6\% over Logan's thickness. Regardless of the exact correlation, the cumulative thicknesses of the measured sections match remarkably well given the brevity of the field work.

Contrary to Dawson's statement, both measured sections contain coal seams that are not present in the other. Dawson recorded Bell's Brook within a 12-foot shale. Depending on its exact placement within this interval, the brook is separated from the next overlying coal by 28 to 40 feet of clastic sediment; however, Logan placed Coal 10 within 6 feet of the brook. (Note that Davies et al. 2005, were unable to locate Coal 10.) Conversely, coals mentioned in Dawson's Groups XVII (8-inch seam), XV (4-inch seam), and XI (4-foot seam) are not reported by Logan. (Note that the 8-inch and 4-foot seam are exposed today; the location of the 4-inch seam is uncertain.)

Unlike the cumulative thickness values, bed-by-bed comparison of the measured sections shows that even distinctive beds have very different descriptions and thicknesses. For example, Logan's measured section has Division 4 capped by a 4 -foot bituminous limestone atop a 1-foot coal (Coal Group 1; Fig. 4A); the same interval is described by Dawson (Group XXVII;
Fig. 4B) as having a 1-foot coal overlain by 1 -foot calcareo-bituminous shale. (Note that Davies et al. 2005, record a $0.38 \mathrm{~m}$ [1 foot, 3 inch] limestone at this level.) Logan's Coal Group 4 (Fig. 4A) consists of an 8-inch coal overlain by 1 foot, 7 inches of argillaceous shale and 2 feet, 7 inches of interbedded coal and carbonaceous shale, whereas Dawson describes the same interval (near the base of Group XXVII; Fig. 4B) as having two 8 -inch coals separated by 4 feet of bituminous shale with coaly layers. Both measured sections specifically mention the Coal Mine Point headland (Fig. 5A, B); Logan quotes the thickness of the sandstone there as 30 feet, but Dawson gives it as 25 feet. (Note that Davies et al. 2005, give the thickness of the sandstone portion of Coal Mine Point as about $7.6 \mathrm{~m}$ [25 feet] thick.)

\section{Reconciliation}

Without explanation, a very different version of the Joggins measured section appears in later printings of Acadian Geology (Dawson 1868, 1878, 1891). At first glance, it appears as if Dawson simplified his measured section and incorporated Logan's numbers; closer inspection reveals that he abandoned many of his own observations and thicknesses in favor of Logan's. The nature of these changes is easily illustrated by comparing Dawson's 1855 and 1868 versions of Subdivisions XXVII, XVI, and I with Logan's measurements from these intervals (Figs. 4, 5). Comparison of the coals in these intervals reveals that Dawson adopted Logan's observations for coals and immediately adjacent strata. This interval also demonstrates that Dawson sometimes used Logan's thicknesses for thick packages of interbedded clastic strata. Dawson also made it impossible to compare thicknesses between the revised version of his measured section and Logan's by excluding the thickness of many units immediately above (shales) or below (underclays) coals (Figs. 4C, 5C). Although Dawson stated at the end of the measured section that the "total thickness of Division 4, according to Logan's measurements" is 2539 feet, 1 inch, the sum of all the values he listed is actually 2583 feet, 3 inches (which is a minimum value because of the missing thicknesses for units above and below coals).

Fortunately, Dawson inserted text blocks with his own observations to supplement Logan's basic lithologic descriptions. More importantly, he also inserted several of the coals that Logan missed. These additional coal-bearing packages are designated with a letter suffix (e.g., Coal Groups 13a, 15a, and 29a). The only explanation of the overlooked seams is given with regards to Coal Group 29a: "My measurements in this part of the section differ somewhat from those of Sir W.E. Logan, who, I suppose, had not a good opportunity of examining the two last coals. The coal 29a is now mined by an adit from the shore, called the "New Mine" (Dawson 1868).

Dawson's decision to abandon his own measurements was unfortunate because, if number of hours per unit thickness is any indication of quality, Dawson and Lyell certainly had the superior measured section. We are not aware of any documentation explaining why Dawson chose to abandon his own observations in favor of Logan's, but it seems likely that Dawson 

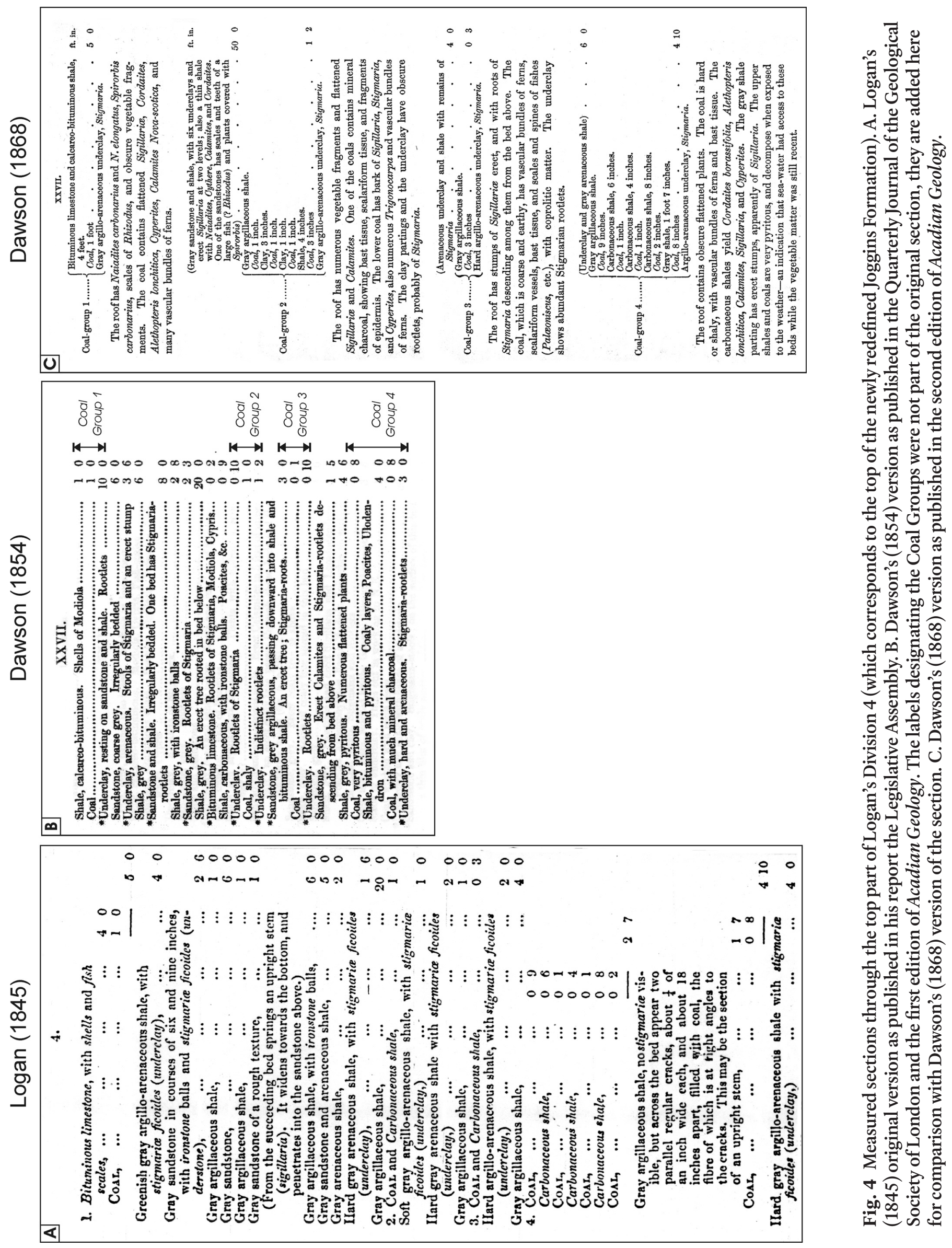

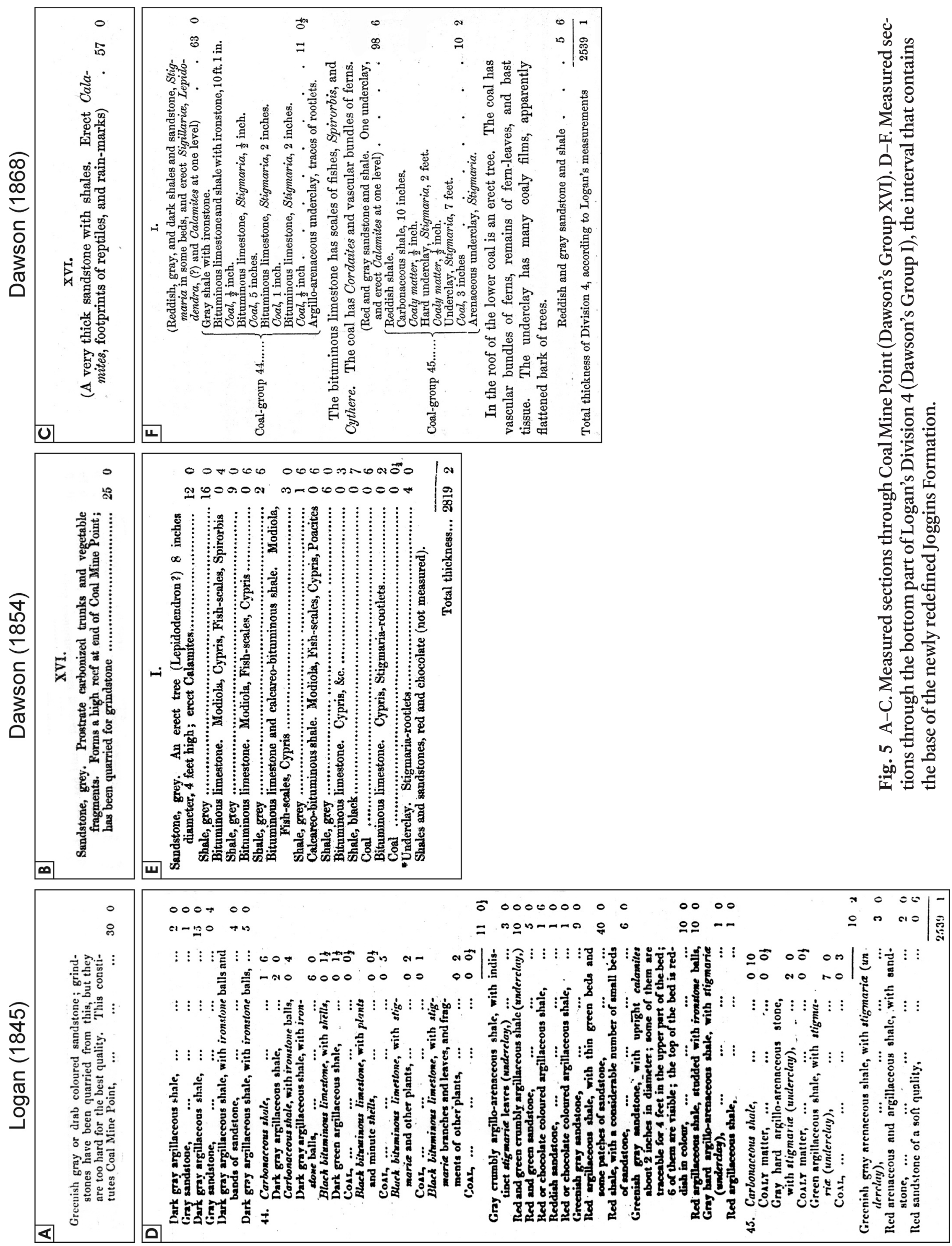

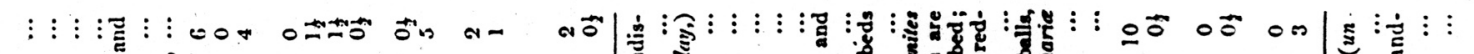

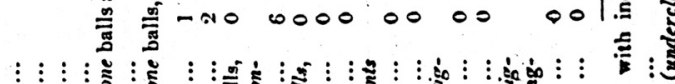

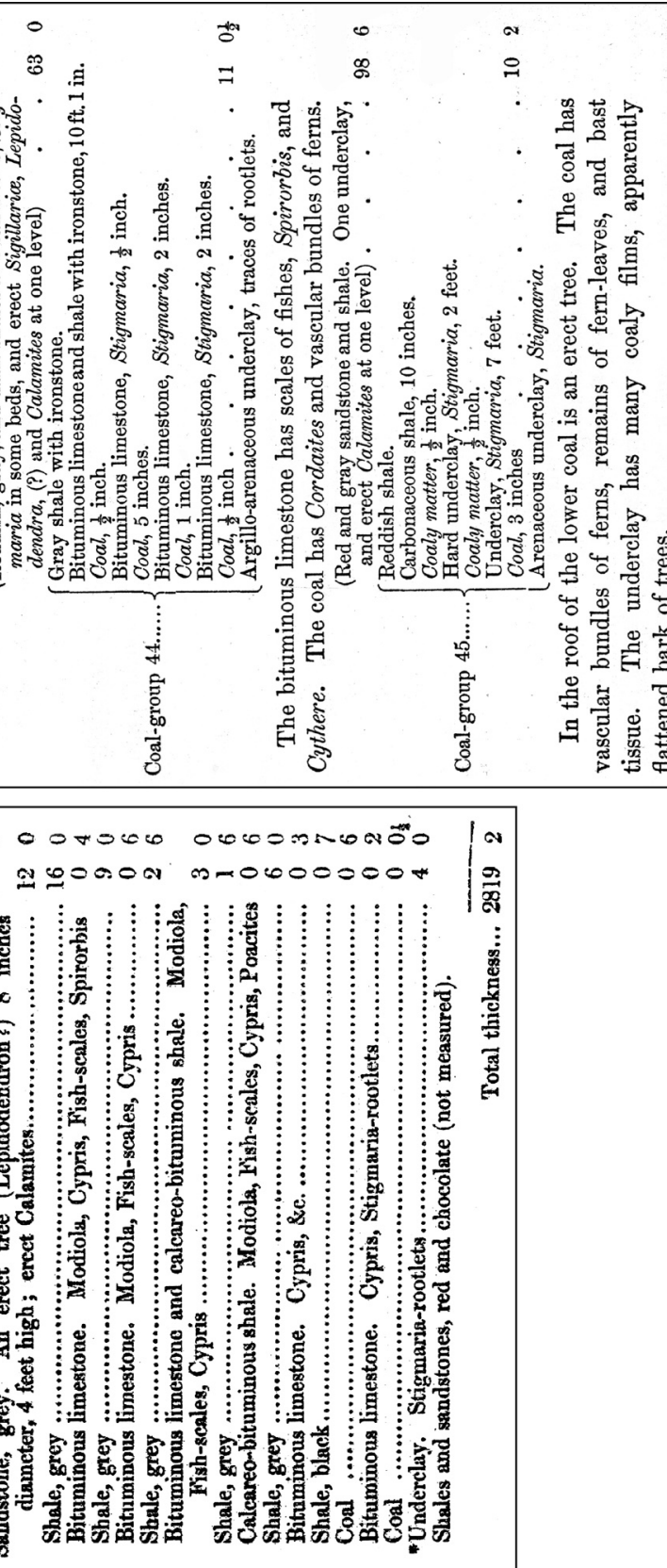

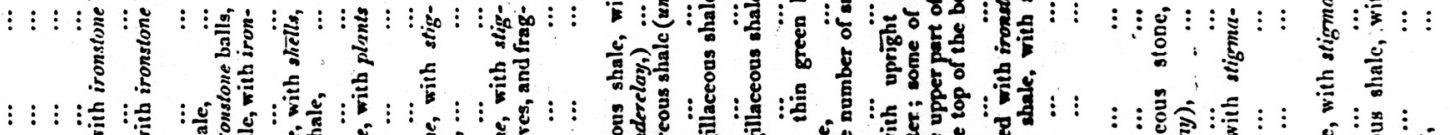
: : : : :

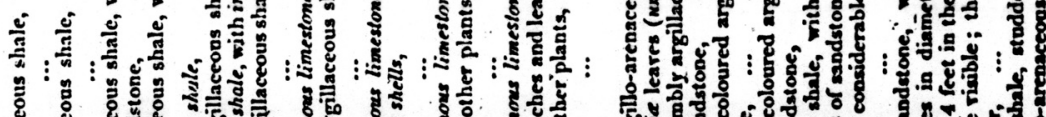

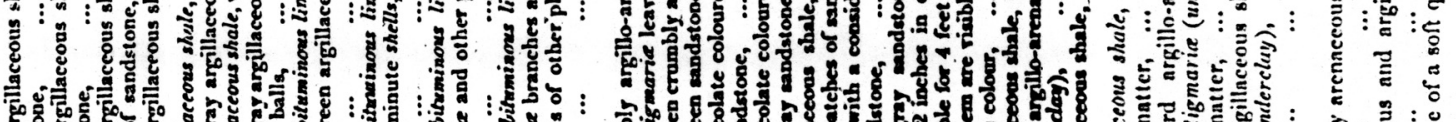

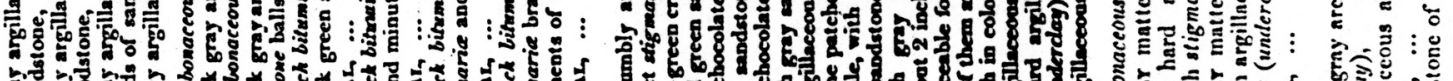

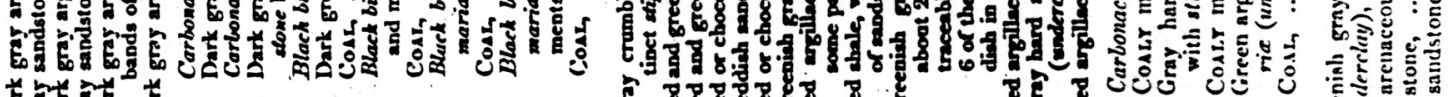

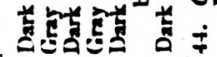

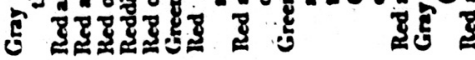
ปั 
made this decision to abandon his measurements for the sake of simplicity and to publicize the largely unknown work of his colleague from twenty-five years earlier. Certainly, it made no sense to have two competing sections, and Logan was the senior geologist and had published his version first. Although Dawson's revised version has only limited value as a bed-by-bed measured section, it does contribute a wealth of paleontological and interpretive information, something almost completely lacking from Logan's measured section.

\section{SIGNIFICANCE OF THE MEASURED SECTIONS}

Our findings dispel the notion that Logan produced a bedby-bed measured section accurate to fractions of an inch, but highlight other aspects of his work that are even more remarkable. Logan measured more than 14570 feet 11 inches of section in only five days. This monumental feat was accomplished in spite of the access problems caused by the Fundy tides and without the aid of a trained field assistant. Logan's thicknesses for Divisions 4, 5, and 6 are surprisingly close to the values reported by recent detailed studies (Table 1), an impressive accomplishment considering the brevity of his visit and the inherent difficulties with pacing in rough, irregular terrain. Sixteen decades later, Logan's measured section remains the only complete measured section of the strata exposed along the Chignecto coast. The three studies listed in Table 1, combined, comprise just over half of the interval covered by Logan in his five-day traverse.

The Joggins measured section constructed by Logan(1845), and the modified versions that appeared in post- 1855 editions of Dawson's Acadian Geology, are the foundation upon which all subsequent studies were based. The sections and the discoveries made while constructing them are featured in some of the most important scientific works of the nineteenth century, including Darwin's (1859) On the Origin of Species and in Lyell's (1862) Principles of Geology. Regardless of the stratigraphic rank and exact thickness assigned to Logan's Divisions, 160 years of revisions make it clear that Logan essentially got the major lithostratigraphic divisions correct at his first attempt (Fig. 6). With the redefinition of the Joggins Formation and the establishment of the Little River Formation (Calder et al.
2005; Davies et al. 2005), many of the stratigraphic boundaries exposed along the coast now correspond almost exactly to the contacts between Logan's Divisions (Fig. 6). The balance between "lumping" and "splitting" may well shift in the future, but Logan's observations will continue to form the framework upon which the nomenclature is built.

When Logan measured the section at Joggins in June 1843, it was done for his own specific reasons, as he underwent the transition from a gentlemanly amateur to an official government geologist. Nevertheless, it remains one of the single greatest contributions to the geology of the Maritimes. Although our research shows that Logan's section should no longer be considered a detailed, bed-by-bed measured section, the story behind its construction shows that it remains "a remarkable monument of his industry and power of observation” (Harrington 1883).

\section{ACKNOWLEDGEMENTS}

Martin Gibling (Dalhousie University) and John Calder (Nova Scotia Department of Natural Resources) encouraged the development of this manuscript and provided valuable input on early drafts. Suggestions by Peter von Bitter, Rob Fensome, and an anonymous reviewer greatly improved the manuscript. Our examination of Logan's time at Joggins would not have been possible had Charles Smith (Geological Survey of Canada) not informed us of our mutual interests. Leonard G. Wilson (University of Minnesota) provided transcripts of Lyell's notes from Joggins in 1852. We thank Tom Sharpe (Department of Geology, National Museums \& Galleries of Wales) and Derek Siveter (Arkell Library, Oxford University Museum of Natural History) for providing transcripts of letters in the De la Beche and Phillips collections, respectively. We acknowledge the Oxford University Museum of Natural History and the National Museums and Galleries of Wales for granting us permission to quote archival manuscripts. MCR was supported by a Killam Predoctoral Scholarship and a Natural Sciences and Engineering Research Council grant to Martin Gibling and the GSA History of Geology Division's Student Award. BCS acknowledges the support of the Killam Trust and of a Social Sciences and Humanities Research Council Doctoral Fellowship.

Table 1. Summary of measured thicknesses for Logan's Divisions 4, 5, and 6.

\begin{tabular}{cllll}
\hline Division & \multicolumn{1}{c}{ Present name } & \multicolumn{1}{c}{ Logan's thickness } & \multicolumn{1}{c}{ Thickness $(\mathrm{m})$ \& Author } & $\begin{array}{c}\text { Difference from } \\
\text { Logan's thickness }\end{array}$ \\
\hline 4 & Joggins Formation & $773.9 \mathrm{~m}(2,539 \mathrm{ft} .1 \mathrm{in})$. & $915.5 \mathrm{~m}$ (Davies et al. 2005) & $141.6 \mathrm{~m}(+18.3 \%)$ \\
5 & Little River Formation & $634.6 \mathrm{~m}(2,082 \mathrm{ft})$. & $635.8 \mathrm{~m}$ (Calder et al. 2005) & $1.2(+0.2 \%)$ \\
6 & Boss Point Formation & $987.8 \mathrm{~m}(3,240 \mathrm{ft} .9 \mathrm{in})$. & $\begin{array}{l}1074 \mathrm{~m} \text { (S. Johnson \& C. St. Peter, } \\
\text { personal communication, 2003) }\end{array}$ & $86.2 \mathrm{~m}(+8.7 \%)$
\end{tabular}




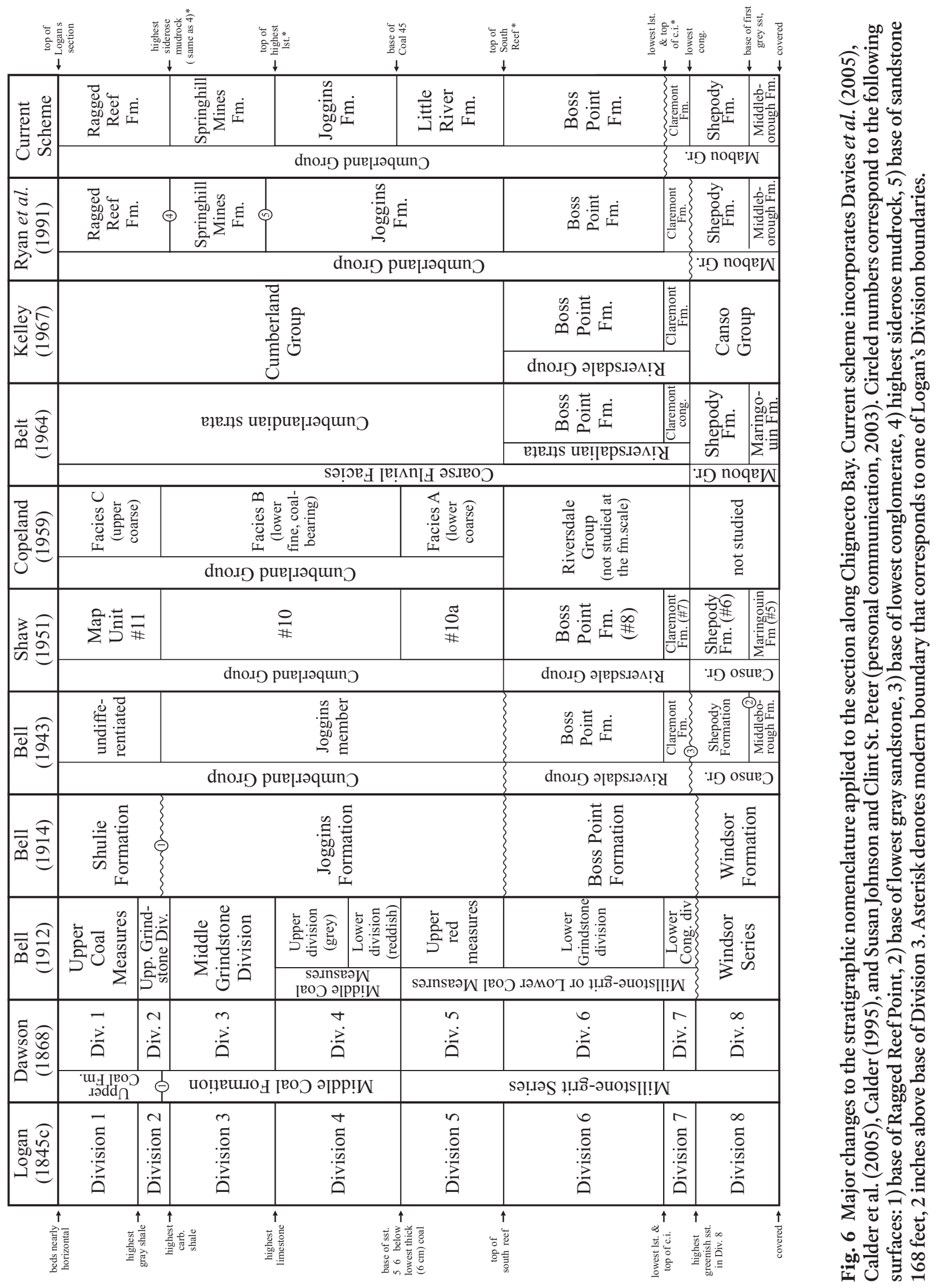




\section{REFERENCES}

Alcock, E.J. 1948. The father of Canadian geology. The Earth Science Digest, 2, pp. 5-10.

BAILEy, E. 1952. Geological Survey of Great Britain. London, Murby, $278 \mathrm{p}$.

BELL, W.A. 1912. Joggins Carboniferous section of Nova Scotia. Geological Survey of Canada, Summary Report for 1911, pp. 328-333.

BELL, W.A. 1914, Joggins Carboniferous section, Nova Scotia. Geological Survey of Canada, Summary Report for 1912, pp. 360-371.

BELL, W.A. 1943, Carboniferous rocks and fossil floras of northern Nova Scotia. Geological Survey of Canada, Memoir 238, $276 \mathrm{p}$.

BeLt, E.S. 1964. Revisions of Nova Scotia middle Carboniferous units. American Journal of Science, 262, pp. 653-673.

Brown, R., \& Smith, R. 1829. Geology and mineralogy. In A historical and statistical account of Nova Scotia. Edited by T.C. Haliburton. Halifax, Joseph Howe, Section 3, 2, pp. 414-453.

Calder, J.H. 1985. Coal in Nova Scotia. Halifax, Nova Scotia Department of Mines and Energy, $79 \mathrm{p}$.

CALDER, J.H. 1995. Geological map of the Springhill Coalfield, Cumberland County, Nova Scotia [parts of 21H09A and D]. Nova Scotia Department of Natural Resources, Map ME 1995-1, scale 1:10 000.

Calder, J.H., Rygel, M.C., Gibling, M.R., Ryan, R.J., FalCON-LANG, H.J., \& HeBERT, B.L. 2005. Stratigraphy and sedimentology of early Pennsylvanian red beds at Lower Cove, Nova Scotia, Canada: the Little River Formation with redefinition of the Joggins Formation. Atlantic Geology, 41, pp. 143-167.

Christie, N. 1995. Sir William Logan's geological empire and the 'humbug' of economic utility. Canadian Historical Review, 75, pp. 161-204.

Canadian Institute for Historical MicroreproducTIONS (NOW CANADIANA.org). 2005. ECO: Early Canadiana Online website, $<\mathrm{http}$ :/www.canadiana.org $>$, Logan's Appendix W begins at $<$ http://www.canadiana.org/ECO/ PageView/9_00955_4_1/0526>

Copeland, M.J. 1959. Coalfields, west half Cumberland County, Nova Scotia. Geological Survey of Canada, Memoir 298, 89 p.

DARWIN, C. 1859. On the origin of species by means of natural selection. $1^{\text {st }}$ Edition. Murray, London, $513 \mathrm{p}$.

Davies, S.J., Gibling, M.R., Rygel, M.C., \& Calder, J.H. 2005. The Pennsylvanian Joggins Formation of Nova Scotia: stratigraphic framework and sedimentological log of the historic fossil cliffs. Atlantic Geology, 41, pp. 115-142.

Dawson, J.W. 1854. On the coal measures of the South Joggins, Nova Scotia. Quarterly Journal of the Geological Society of London, 10, pp. 1-42.

Dawson, J.W. 1855. Acadian geology. An account of the geological structure and mineral resources of Nova Scotia, and portions of the neighbouring provinces of British America. $1^{\text {st }}$ Edition. Oliver and Boyd, Edinburgh, $388 \mathrm{p}$.

Dawson, J.W.1868. Acadian geology. The geological structure, organic remains, and mineral resources of Nova Scotia, New Brunswick, and Prince Edward Island. ${ }^{\text {nd }}$ Edition. Macmillan, London, $694 \mathrm{p}$.

Dawson, J.W.1878. Acadian geology. The geological structure, organic remains, and mineral resources of Nova Scotia, New Brunswick, and Prince Edward Island. $3^{\text {rd }}$ Edition. Macmillan, London, $825 \mathrm{p}$.

Dawson, J.W. 1891. The geology of Nova Scotia, New Brunswick, and Prince Edward Island; or, Acadian geology. $4^{\text {th }}$ Edition. Macmillan, London, 694 p.

Dawson, J.W. 1901. Fifty years of work in Canada. Ballantyne, Hanson \& Co., London \& Edinburgh, 308 p.

De la Beche, H.T., Papers. NMW 84.20G.D. Department of Geology, National Museums \& Galleries of Wales, Cardiff, U.K.

Dотт, R.H. 1996. Charles Lyell in America; his lectures, field work, and mutual influences, 1841-1853. Earth Sciences History, 15, pp. 101-140.

Freese, B. 2003. Coal: A human history. Perseus, Cambridge, Massachusetts, $308 \mathrm{p}$.

Gesner, A. 1836. Remarks on the geology and mineralogy of Nova Scotia. Gossip and Coade, Halifax, 272 p.

Harrington, B.J. 1883. Life of Sir William E. Logan. Dawson Brothers, Montreal, $432 \mathrm{p}$.

Horner, L. 1846. Anniversary address of the President [26 February 1846]. Quarterly Journal of the Geological Society of London, 2, pp. 145-221.

Jackson, C.T., \& Alger, F. 1828. A description of the mineralogy and geology of a part of Nova Scotia. American Journal of Science, 14, pp. 305-330.

KeLLEy, D.G. 1967. Some aspects of Carboniferous stratigraphy and depositional history in the Atlantic Provinces. In Collected papers on geology of the Atlantic Region: Hugh Lilly Memorial Volume. Edited by E.R.W. Neale and H. Williams. Geological Association of Canada, Special Paper 4, pp. 213-228.

Library ANd ARChives CANAdA. 2005. Written in Stone website, $<$ http://www.collectionscanada.ca/logan $>$, the digital collections referred to in this paper are available at $<\mathrm{http}$ : //www.collectionscanada.ca/logan/021014-3000-e.html>

Logan, W.E., PAPERs. McGill University Archives, Montreal, Quebec, Canada.

LOGAN, W.E. 1840. On the character of the beds of clay lying immediately below the coal seams of South Wales. Proceedings of the Geological Society of London, 3, pp. 275-277

Logan, W.E. 1841a. Memoranda: Canada \& the United States 1840-41. manuscript (diary), Toronto Reference Library Baldwin Room Manuscripts Collection, Ontario, Canada, available online at: http://www.collectionscanada.ca/logan/ 021014-3200-e.html

Logan, W.E. 1841b. On the coal fields of Pennsylvania and Nova Scotia. Proceedings of the Geological Society of London, 3, p. 707. 
LOGAN, W.E. 1842a. On the character of the beds of clay lying immediately below the coal seams of South Wales. Transactions of the Geological Society of London, ser. 2, 6, pp. 491-497.

LogAN, W.E. 1842b. On the packing of ice in the river Saint Lawrence. Proceedings of the Geological Society of London, 3, pp. 766-770.

Logan, W.E. 1843a. Joggins, Bay of Fundy, Nova Scotia (1842-1843). Logan's Field Notebook, National Archives of Canada, RG45, vol. 158, item 1962, available online at http: //www.collectionscanada.ca/logan/021014-5000.02-e.php

LogAn, W.E. 1843b. Bay of Chaleur - Bay of Fundy (1843). Logan's Field Notebook, National Archives of Canada, RG45, vol. 158, item 2606, available online at http:// www.collectionscanada.ca/logan/021014-5000.11-e.php

Logan, W.E. 1845. Appendix W: Geological Survey. In Appendix, No. 1, to the Fourth Volume, Journals of the Legislative Assembly of the Province of Canada, 1844-5, 4, Canadian Institute for Historical Microreproductions number 9 00955_4_1, available online at $<\mathrm{http}$ ://www.canadiana.org/ ECO/PageView/9_00955_4_1/0526>. The Joggins measured section begins at image W-29: http://www.canadiana.org/ ECO/PageView/9_00955_4_1/0554

LogAN, W.E. 1846. On the packing of ice in the River Saint Lawrence; the occurrence of landslips in the modern deposits of its valley; and the existence of marine shells in them and on the mountain of Montreal. Quarterly Journal of the Geological Society of London, 2, pp. 422-432.

Lyell, C., Papers. Gen. 113/3500-01. Special Collections, Edinburgh University Library, Edinburgh, U.K.

Lyell, C. 1842. Notebook 103. Kinnordy MSS collection, Kinnordy House, Scotland, pp. 142.

Lyell, C. 1843a. On the upright fossil-trees found at different levels in the coal strata of Cumberland, Nova Scotia. Proceedings of the Geological Society of London, 4, pp. 176-178.

LYeLL, C. 1843b. On the coal-formation of Nova Scotia, and on the age and relative position of the gypsum and accompanying marine limestones. Proceedings of the Geological Society of London, 4, pp. 184-186.

Lyell, C. 1845. Travels in North America, in the years 1841-2; with geological observations on the United States, Canada, and Nova Scotia. Murray, London, 2, 272 p.

Lyell, C. 1862. Principles of Geology. $9^{\text {th }}$ Edition. Appleton \& Co., New York, 834 p.

LYELL, C., \& DAWSON, J.W. 1853. On the remains of a reptile (Dendrerpeton acadianum Wyman and Owen), and of a land shell discovered in the interior of an erect fossil tree in the coal measures of Nova Scotia. Quarterly Journal of the Geological Society of London, 9, pp. 58-63.

LYELL, K.M. 1881. Life, letters, and journals of Sir Charles Lyell. Murray, London, 2, 506 p.

Phillips, J., Papers. Arkell Library, Oxford University Museum of Natural History, Oxford, U.K.

Poole, H.S. 1908. A section of Carboniferous rocks in Cumberland County, Nova Scotia; (1) Detailed section of rocks from West Ragged Reef to the Joggins mines and Minudie, by Sir William E. Logan(republished); and (2) From Schulie to Spicer Cove, by Hugh Fletcher. Proceedings and Transactions of the Nova Scotian Institute of Science, 11, pp. 417-550.

Ryan, R.J., Boehner, R.C., \& CALDER, J.H. 1991. Lithostratigraphic revisions of the upper Carboniferous to lower Permian strata in the Cumberland Basin, Nova Scotia and the regional implications for the Maritimes Basin in Atlantic Canada. Bulletin of Canadian Petroleum Geology, 39, pp. 289-314.

Sharpe, T., \& McCartney, P.J. 1998. The Papers of H.T. De la Beche (1796-1855) in the National Museum of Wales. Cardiff, Wales, National Museum of Wales, Geological Series Number 17.257 p.

SHaw, W.S. 1951, Preliminary map, Springhill, Cumberland, and Colchester counties, Nova Scotia: Geological Survey of Canada, Paper 51-11.

Sheets-Pyenson, S. 1996. John William Dawson: faith, hope, and science. McGill-Queen's University Press, Montreal \& Kingston, $304 \mathrm{p}$.

Shipley, B.C. 2001. 'I wish these annual reports were at the devil': William E. Logan and the publications of the Geological Survey of Canada. Presented at the History of the Book in Canada, Open Conference for Volume II, Montreal. Available online at http://www.hbic.library.utoronto.ca/ vol2shipley_en.htm

Shipley, B.C. 2002. Rough science in the bush. The Beaver, 82, Feb-Mar, pp. 8-15.

Smith, C.H. 2000. Sir William Edmond Logan, father of Canadian geology: his passion was precision. GSA Today, 10, pp. 22-23.

Stevenson, J.J. 1911. The formation of coal beds. Proceedings of the American Philosophical Society, 50, pp. 1-116.

Torrens, H.S. 1999. William Edmond Logan's geological apprenticeship in Britain 1831-1842. Geoscience Canada, 26, pp. 97-110.

von BITTER, P.H. 1998. Sir William Logan's geological maps of Canada; field methods and scientific instruments. $\mathrm{Ab}$ stracts with Programs - Geological Society of America, 30, pp. 101.

Wilson, L.G. 1998. Lyell in America: transatlantic geology, 1841-1853. The Johns Hopkins University Press, Baltimore, $429 \mathrm{p}$.

ZASLOw, M. 1975. Reading the rocks; the story of the Geological Survey of Canada, 1842-1972. Ottawa, Macmillan, 599 p.

Zeller, S. 1987. Inventing Canada. University of Toronto Press, Toronto, $356 \mathrm{p}$.

Editorial responsibility: Robert A. Fensome 